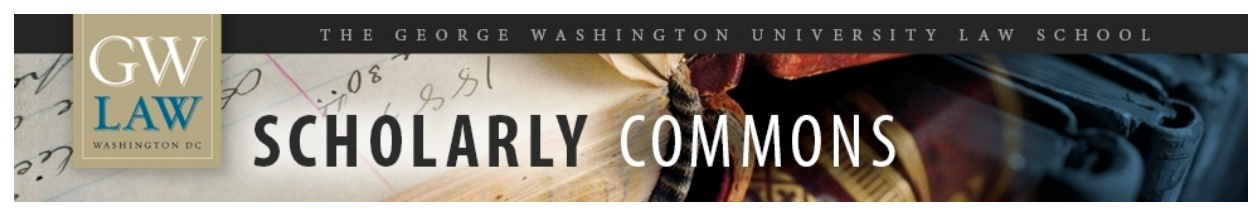

\title{
The Inevitable Legal Pluralism within Universal Harmonization Regimes: The Case of the Cisg
}

\author{
Paul Schiff Berman \\ George Washington University Law School, pberman@law.gwu.edu
}

Follow this and additional works at: https://scholarship.law.gwu.edu/faculty_publications

Part of the Law Commons

\section{Recommended Citation}

Berman, Paul Schiff, The Inevitable Legal Pluralism within Universal Harmonization Regimes: The Case of the Cisg (2016). Unif. L. Rev., 2016, 1-18 ; GWU Law School Public Law Research Paper No. 2016-7; GWU Legal Studies Research Paper No. 2016-7. Available at SSRN: http://ssrn.com/abstract=2749847

This Article is brought to you for free and open access by the Faculty Scholarship at Scholarly Commons. It has been accepted for inclusion in GW Law Faculty Publications \& Other Works by an authorized administrator of Scholarly Commons. For more information, please contact spagel@law.gwu.edu. 


\title{
The inevitable legal pluralism within universal harmonization regimes: the case of the CISG
}

\author{
Paul Schiff Berman*
}

\begin{abstract}
Faced with a world of multiple overlapping normative communities and jurisdictions, law often seeks universal rules and harmonization regimes. Such rules and regimes offer to tame pluralism through the imposition of common codes of conduct. The 1980 Convention on Contracts for the International Sale of Goods (CISG) is a useful example of this phenomenon. Arising from harmonization efforts dating back at least to the 1920s, the CISG purports to solve the problem of jurisdictional overlap and inconsistency in the application of domestic law to cross-border commercial transactions. To its backers, the CISG addresses intractable problems of legal uncertainty and forum shopping, creating a stable global law of trade. Thus, the CISG resolutely seeks uniformity, and those most committed to the treaty and its implementation tend to see any inconsistency in application as a problem to be solved rather than a necessary feature of how even a harmonization regime must operate in a multivariate word. This brief article takes the opposite approach, suggesting some ways in which legal pluralism inevitably creeps into the CISG regime, and treating such areas of pluralism as a reality that will never (and perhaps should never) disappear completely.
\end{abstract}

\section{Introduction}

Faced with a world of multiple overlapping normative communities and jurisdictions, law often seeks universal rules and harmonization regimes. Such rules and regimes offer to tame pluralism through the imposition of common codes of conduct. The 1980 Convention on Contracts for the International Sale of Goods

\footnotetext{
* Walter S. Cox Professor of Law, George Washington University Law School, Washington, DC, USA. Email: pberman@law.gwu.edu. Some material in this article is derived from Paul Schiff Berman, 'Ruth Bader Ginsburg and the Interaction of Legal Systems' in Scott Dodson (ed), The Legacy of Ruth Bader Ginsburg (Cambridge University Press 2015); Paul Schiff Berman, Global Legal Pluralism: A Jurisprudence of Law beyond Borders (Cambridge University Press 2012); Paul Schiff Berman, 'Seeing Beyond the Limits of International Law (reviewing Jack L Goldsmith and Eric A Posner, the Limits of International Law)' (2006) 84 Texas Law Review 1265. Special thanks to Jamie Noonan for helpful research assistance in the preparation of this manuscript.
}

(C) The Author (2016). Published by Oxford University Press on behalf of UNIDROIT. All rights reserved. For Permissions, please email journals.permissions@oup.com 
(CISG) is a useful example of this phenomenon. ${ }^{1}$ Arising from harmonization efforts dating back at least to the 1920s, the CISG purports to solve the problem of jurisdictional overlap and inconsistency in the application of domestic law to cross-border commercial transactions. To its backers, the CISG addresses intractable problems of legal uncertainty and forum shopping, creating a stable global law of trade. Thus, the CISG resolutely seeks uniformity, and those most committed to the treaty and its implementation tend to see any inconsistency in application as a problem to be solved rather than as a necessary feature of how even a harmonization regime must operate in a multivariate word. This brief article takes the opposite approach, suggesting some ways in which legal pluralism inevitably creeps into the CISG regime, and treating such areas of pluralism as a reality that will never (and perhaps should never) disappear completely.

Of course, to some degree, the entire project of the CISG is an acknowledgment of legal pluralism. Indeed, the scheme of developing an overarching transnational law of commercial trade hearkens back to the mythical idea of a lex mercatoria that operates independently of formal state law. ${ }^{2}$ The CISG, like the Uniform Commercial Code in the USA, ${ }^{3}$ is meant to codify law as it is already being practised in day-to-day commercial encounters. These are 'the unwritten customary rules of the trade' that theorist Gunther Teubner and others have identified as an independent social system that can sometimes harden into formal law. ${ }^{4}$ Thus, the CISG is inherently a pluralist instrument, one that recognizes the independent valence of non-state customary norms and seeks to systematize those norms into a form of 'hard law'. However, as we will see, the document is not only itself the product of pluralism; it inevitably contains pluralism within it.

\section{The pluralism within the CISG}

The inherent pluralism of the CISG does not simply get codified into an international law instrument and thereby lose all of its pluralism. For although the impulse behind the CISG is to harmonize contract law and eliminate pluralism, diversity inevitably creeps back in. We can observe a number of ways in which this process of pluralism occurs.

1 UN Convention on Contracts for the International Sale of Goods 1489 UNTS 3 (1980).

2 See, eg, Clayton P Gillette, 'The Law Merchant in the Modern Age: Institutional Design and International Usages under the CISG' (2004) 5 Chicago Journal of International Law 157, 159 (noting that the Convention 'explicitly incorporates trade usages into contracts that it governs, permits usages to trump conflicting [Convention] provisions, and authorizes courts to interpret and complete contracts by reference to usages'). But see Celia Wasserstein Fassberg, 'Lex Mercatoria: Hoist with Its Own Petard?' (2004) 5 Chicago Journal of International Law 67 (arguing that the modern revival of lex mercatoria departs significantly from the historical conception).

3 See Zipporah Batshaw Wiseman, 'The Limits of Vision: Karl Llewellyn and the Merchant Rules' (1987) 100 Harvard Law Review 465, 503-19 (describing Karl Llewellyn's initial drafts of what later became Article 2 of the Uniform Commercial Code).

4 Gunther Teubner, 'The Two Faces of Janus: Rethinking Legal Pluralism' (1992) 13 Cardozo Law Review 1443, 1449. 


\section{Interpretation of Article 7(1)}

First, we can identify what seems like the most straightforward harmonization statement in the entire Convention, Article 7(1), which states that in the interpretation of this Convention, regard is to be had to its international character and to the need to promote uniformity in its application and the observance of good faith in international trade'. At first blush, this provision seems to be a strong harmonization plea, not an avenue for pluralism. The message is clear: do not advance parochial or divergent local interests at the expense of uniformity.

And yet, even here at its most internationalist, the Convention necessarily permits radically different interpretations of what counts as 'regard' for the document's 'international character'. ${ }^{5}$ For example, a common law judge, seeking uniformity, might look immediately to the interpretations of the Convention previously set forth by other judges based on other factual scenarios. And, then, like all good common law judges, the judge would analogize and distinguish those cases in order to seek the best fit and justification for the overall international harmony of the doctrine.

In contrast, a civil law judge, faced with the same admonishment, would eschew looking at judicial opinions and instead give weight to scholarly commentary and exposition that aims to explain the Convention's text and shape it into a unified whole. Thus, faced with a prior court interpretation criticized by scholars, a civil law judge is likely to embrace the scholarly commentary and discount the judicial opinion, while the common law judge is likely to do just the reverse. And yet both judges would be applying the principle of Article 7(1) and acting in the name of uniformity!

Accordingly, it is clear that, even when participants embrace the Convention's universalist aims, the results need not always be uniform. This is no surprise to socio-legal scholars who, for decades, have charted the myriad ways in which the law 'on the books' does not necessarily match the 'law in action' as actually interpreted and applied in everyday life. As a result, any desire for uniformity is always likely to be thwarted, at least around the margins.

Ironically, the fact that the CISG allows multiple approaches to uniformity may be partly responsible for its widespread adoption by different countries. As Vivian Curran has pointed out, the CISG is both a 'seamless text that precedes the cases', qualifying it as law to the civil law mind, and a law whose uniformity and coherence over time will be created by judicial opinions interpreted pursuant to Article $7(1)$, just as the common law method expects. ${ }^{6}$ The CISG therefore appeals to both civil law and common law mindsets, and this pluralism at the core of the CISG is undoubtedly a fundamental reason it has been so widely adopted and used.

\footnotetext{
5 See Vivian Grosswald Curran, 'A Comparative Perspective on the CISG' in Harry M Flechtner et al (eds), Drafting Contracts under the CISG (Oxford University Press 2008) 49, 50 (pursuing differences between common and civil law approaches to uniformity).

6 Ibid 60.
} 


\section{Issues excluded from the CISG}

A second sphere of pluralism lies in all of the many areas of transnational contract that are expressly excluded from the CISG. Most importantly, Article 2(a) leaves the extremely important field of consumer contracts out of the purview of the CISG altogether. States differ greatly in their efforts to strike the balance between the rights of vendors and the rights of consumers, particularly at a time when the rise of boilerplate and contracts of adhesion has put pressure on the traditional conception of contracts simply as bargained-for exchanges among negotiating partners. ${ }^{7}$ At least in the consumer context, unequal power between the parties to the contract has rendered such contracts more akin to elements of the product itself, potentially to be governed by tort law and consumer protection legislation not by contract law. In this significant area, the CISG holds no sway, letting many pluralist flowers bloom.

The CISG also explicitly excludes questions of contract validity from its purview. Article 4 makes clear that the Convention addresses only contract formation and the interpretation of rights and obligations under the contract itself. Accordingly, if a State chooses to adopt a robust law of unconscionability, for example, that law might be interposed to declare a contract invalid regardless of the provisions of the CISG. Again, this clause allows for significant pluralism because of the potential to impose public policy requirements on questions of whether a valid contract was formed in the first place.

\section{Lacunae in the text of the CISG}

Third, even with regard to matters generally within the ambit of the Convention, there are, inevitably, lacunae. Article 7(2) focuses on such lacunae when the Convention seems to cover a topic but does not expressly provide a rule to resolve that issue. In an effort to fend off pluralism, Article 7(2) first states that if the Convention does not expressly settle a 'question[] concerning [a] matter[] governed by this Convention,' then courts are to look to 'the general principles on which [the Convention] is based' to answer the question. In the absence of general principles, which should be rare, Article 7(2) directs interpreters to 'the law applicable by virtue of the rules of private international law,' which are also known as conflict-of-law rules.

The classic example of a 'gap' within the Convention is Article 78. Article 78 provides that ' $\mathrm{i}$ ] f a party fails to pay the price or any other sum that is in arrears, the other party is entitled to interest on it'. Here, although the Convention provides that the other party is entitled to interest, it does not offer any guidance regarding how the interest is to be calculated. ${ }^{8}$ And, not surprisingly, courts and commentators have endlessly debated the matter.

7 For a discussion of these concerns, see generally Margaret Jane Radin, Boilerplate: The Fine Print, Vanishing Rights, and the Rule of Law (Princeton University Press 2012).

8 For a discussion of Article 78, its history and application, see Francesco G Mazzotta, 'CISG Article 78: Endless Disagreement among Commentators, Much Less among the Courts’ <http://www. cisg.law.pace.edu/cisg/biblio/mazzotta78.html> accessed 14 July 2015. 


\section{Ambiguity in the text of the CISG}

A fourth area of pluralism arises where the provisions of the Convention themselves are sufficiently ambiguous that they are internally open to interpretation. Such ambiguities inevitably provide opportunities for judges and arbitrators to diverge in their application of a given contractual provision. As Paul Stephan has argued:

[t] he very extent of the convention, as well as the rules applicable to contracts within its coverage, remains sufficiently unclear to allow decisionmakers to make almost any choice they wish. Moreover, even when the language of the CISG follows that of preexisting rules, such as those of Article 2 of the UCC, it still displaces the clarifying glosses that national courts have given to domestic law. ${ }^{9}$

These ambiguities are yet another form of gap, and they may be inevitable, given that the drafters needed to create a document that would satisfy so many signatory nations. Not surprisingly, differences of opinion were papered over in vague language that could appeal to all.

The result, however, is not uniformity but, rather, a potential pluralism of interpretations. Let us try out some concrete examples. ${ }^{10}$ Assume that a corporation in one signatory state—say, Germany-enters into a contract with a corporation from another signatory state-say, the USA. Article 1(1)(a) states that the Convention governs contracts 'between parties whose places of business are in different states', each of which has joined the Convention. Thus, it appears straightforward that the Convention will apply to this contract. However, what if the German corporation has a US office that handles all contractual matters related to US businesses? Does this still count as a German corporation, or will this contract no longer be governed by the CISG? According to Article 10(a) of the Convention, if a party has more than one place of business, that 'which has the closest relationship to the contract and its performance' is the one that matters. But then we have an interpretive question. Is the relevant place of business the US office of the German corporation, which is where the contract was presumably negotiated and administered, or is it the German location where, perhaps, the goods at issue are manufactured or from which they are shipped?

Similarly, we can imagine ambiguities as to whether a given contract primarily concerns goods, which would make the contract subject to the Convention, or services, which would not, pursuant to Article 3(2)—for example, if the contract required the German company not only to sell equipment but also to provide maintenance, customization of the equipment, and training as to its use. In this scenario, are the goods or the services the 'preponderant' aspect of the contract?

Next, as noted above, the CISG purports to exclude questions of contract validity from its ambit. It is sometimes difficult, however, to separate out a validity question from a question of the contract's substantive terms. For example, if a

9 Paul B Stephan, 'The Futility of Unification and Harmonization in International Commercial Law' (1999) 39 Virginia Journal of International Law 743, 774.

10 These examples are derived from Paul B Stephan, ibid 774-6. 
contract price is stated in Euros, but a local state law in the USA requires that contracts must be in dollars, is that a matter of contract validity to be subject to the local state law or is that merely a pricing term in a contract that the convention covers?

Finally, there is Article 6, which permits parties to 'exclude the application of this Convention or, subject to Article 12, derogate from or vary the effect of any of its provisions'. This seems to be a straightforward party autonomy principle, but courts and commentators can vary regarding whether such an exclusion can occur implicitly or whether instead such an exclusion must be explicit under the terms of the contract itself. ${ }^{11}$ Obviously, this difference in interpretation will result in divergence of the law applicable to the contract.

We could go on and on. Some of these sorts of ambiguities, of course, are inherent in any attempt to produce a legal code. Human activity is simply too varied to be fully captured ex ante by a statute. There will always be gray areas that require subsequent interpretation. Additional ambiguities are inherent in the vagaries of language, which is often imprecise or subject to double meanings. And for an international legal instrument, the imprecision of language is multiplied by the act of translation. Finally, as noted above, still other ambiguities are deliberately left in an international convention because negotiators cannot agree on a definitive meaning or interpretation. However, whatever the reason, it is clear that such ambiguities cannot simply be wished away in the CISG's harmonization effort.

Thus, we see at least four distinct areas where pluralism seeps into the CISG: (1) areas arguably not within the ambit of the Convention; (2) areas covered by the Convention but where gaps can be filled based on general principles of the Convention; (3) areas covered by the Convention, but where gaps are filled by reference to a local choice-of-law principle; and (4) areas where the provisions of the Convention themselves are sufficiently ambiguous that they are internally open to interpretation.

For all of these reasons, it is difficult to deny that legal pluralism is inevitably present, even in this document that seeks unity and harmonization. This is not in any respect meant to be a criticism of the Convention or to suggest that anything incompetent or nefarious took place during the drafting. It is simply to acknowledge that no harmonization scheme ultimately eradicates pluralism entirely.

\section{Why legal pluralism within the CISG is neither a surprise nor a cause for concern}

Is all of this pluralism a cause for concern? Interestingly, most proponents of the CISG seem to think so. Any space for competing interpretations is seen as a problem to be solved rather than a necessary feature of the system. For example, one commentator refers to the fact, discussed above, that the same words in a

11 Franco Ferrari, 'Choice of Forum and CISG: Remarks on the Latter's Impact on the Former' (2005-6) 25 Journal of Law and Commerce 103, 141-2 (citing cases). 
uniform convention can be interpreted differently in different countries as a 'problem [that] cannot be ignored'. ${ }^{12}$ Likewise, another rejects one possible interpretation of Article 1 as running 'counter to the spirit of uniformity' embodied in the CISG. ${ }^{13}$ And, of course, we see multiple websites, scholarly commentaries, and other materials designed to promote the uniformity of interpretation and application of the CISG. ${ }^{14}$

One reason that legal pluralism is viewed as a problem is that advocates of harmonization appear to universally fear the possibility that parties might engage in forum shopping to find the most advantageous law or Convention interpretation. But, is forum shopping necessarily such an evil that it provides a sufficient reason, in and of itself, to choose one jurisdictional scheme over another? Certainly, not without closer scrutiny. As Larry Kramer has pointed out, ' $\mathrm{t}$ ] he assumption that it is unfair to allow plaintiffs to [forum-shop] presupposes a "correct" or "fair" baseline defining how often the plaintiff's choice ought to prevail'. ${ }^{15}$

Indeed, if it is legitimate to have different jurisdictional entities applying distinct bodies of law, why should the law not vary depending on where a suit is brought and why is it necessarily unfair to give parties this choice? Brainerd Currie, arguably the most influential American choice-of-law theorist, downplayed the importance of forum shopping, particularly if preventing it required sacrificing substantive policies. ${ }^{16}$ And even if one believes forum shopping is a problem, it is difficult to evaluate this concern without empirical data. For example, other factors beyond choices about substantive norms may well have a strong impact on forum choice. If most parties consult a local attorney, how many attorneys are willing or able to file suit and litigate in a foreign jurisdiction? How might the existence (or non-existence) of regular referral arrangements affect this choice? Thus, on both normative and empirical grounds, there is at least some cause to question the reflexive concern about excessive forum shopping without further exploration of the extent of the problem. ${ }^{17}$

12 Ibid 139.

13 See Michael Bridge, 'Choice of Law and the CISG: Opting In and Opting Out' in Flechtner et al (n 5) 65,68 .

14 See Ferrari (n 10) 139 (collecting sources).

15 Larry Kramer, 'Rethinking Choice of Law' (1990) 90 Columbia Law Review 277, 313 n 117.

16 See Brainerd Currie, 'Survival of Actions: Adjudication versus Automation in the Conflict of Laws' in Brainerd Currie (ed), Selected Essays on the Conflict of Laws (Duke University Press 1963) (suggesting that, at least in some circumstances, forum shopping is 'positively commendable' and arguing that 'we need to take a harder and closer look at the ideal of uniformity and the condemnation of forum-shopping'). Currie has, of course, been criticized for emphasizing the policies underlying substantive laws to the exclusion of more general choice-of-law policies, such as the need to minimize forum shopping and enhance uniformity and predictability. See, eg, Alfred Hill, 'Governmental Interest and the Conflict of Laws: A Reply to Professor Currie' (1960) 27 University of Chicago Law Review 463, 502-7 (criticizing Currie's approach on the grounds that it multiplies the number of potential conflict situations and does not provide an adequate framework for addressing such conflicts); Arthur Taylor von Mehren, 'Recent Trends in Choice-of-Law Methodology’ (1975) 60 Cornell Law Review 927, 938 (arguing that Currie’s approach to multi-state situations is 'simplistic').

17 Larry Kramer has argued that assertions of unfairness regarding plaintiffs' power to shop for a forum 'rest[] on an unarticulated-and unexplained-assumption about what each party is 
Alongside the forum-shopping concern is a related concern about legal uncertainty. We are told that parties want certainty regarding the law to be applied and that any ambiguity therefore increases transaction costs. However, as with forum shopping, such a concern may not be borne out empirically, at least with regard to contracts. To begin with, it is not at all clear that parties always value certainty above all else. Indeed, too much legal certainty decreases flexibility, which many parties may actually prefer. ${ }^{18}$ After all, in order to achieve certainty, a legal regime must provide more and more detailed rules to cover every situation. But the more such rules that exist, the more likely that the parties will encounter default rules that they actually wish to modify or avoid, requiring them to spend time and effort trying to contract around those default rules. This process of modifying default rules involves the very transaction costs that we are told legal certainty is meant to avoid.

Moreover, the precise legal regime to be applied to a contract—whether certain or uncertain - is often essentially irrelevant to the parties in actual practice, and, therefore, the existence of pluralism is not a significant threat. In his classic study of form contracts in the business-to-business context, Stewart Macaulay revealed that such contracts often remain completely unchanged even when intervening legal developments alter the landscape for such contracts and should have dictated alterations in the contracts themselves. ${ }^{19}$ According to Macaulay, the parties rarely resort to litigation to resolve contract disputes anyway and, therefore, rely upon the relationships and practices built up over an ongoing course of dealing far more than the precise terms of the contract law as interpreted by the courts. As Macaulay recounts, '[c] ontract planning and contract law, at best, stand at the margin of important long-term continuing business relations. Business people often do not plan, exhibit great care in drafting contracts, pay much attention to those that lawyers carefully draft, or honor a legal approach to business relationships'. ${ }^{20}$ Instead, Macaulay argues, 'business cultures' tend to have more impact on contractual relations than the precise legal regime being used.

When we look at cases under the Convention, we see similar evidence that the reality on the ground is less affected by the terms of the Convention than we might initially assume. Indeed, one study of CISG cases in the USA, France, and Germany found that many international sales do not even specify the governing

entitled to expect in a “fair" system'. Larry Kramer (n 15) 313-14 n 117. He 'share[s] the intuition that it is "unfair" if plaintiffs can always choose among the potentially applicable laws' but is 'loath to rely on an intuition that [he] cannot satisfactorily defend simply because it is widely shared'. Ibid $314 \mathrm{n} 117$. Of course, to the extent forum shopping creates uncertainty, parties may attempt to contract around the problem through forum selection and choice-of-law clauses (at least in contractually based cases), or may contractually choose non-litigation alternatives. These 'solutions' depend in part, however, on the law applied to the contractual provisions.

18 See Stephan (n 9) 747.

19 Stewart Macaulay, 'Non-Contractual Relations in Business: A Preliminary Study' (1963) 28 American Sociological Review 55.

20 Stewart Macaulay, 'An Empirical View of Contract' (1985) Wisconsin Law Review 465, 467. 
law to be applied-either the CISG or any other. ${ }^{21}$ For example, in twenty-four out of thirty-eight US cases studied, the parties did not provide for the law governing their contracts, let alone opt in or out of the CISG, and in two other cases the parties had sent standardized forms or unilaterally provided for the applicable law without seeking the agreement of the other party on the issue. ${ }^{22}$ In other words, in twenty-four out of thirty-eight cases, or 63 per cent, the parties were not sufficiently concerned with the applicable law to include a provision in this respect or to ensure that it would be enforceable. Likewise, in Germany, in more than 75 per cent of the cases that discussed the existence of a choice-of-law clause, the parties did not provide for the applicable law to their contract of sale. ${ }^{23}$ And in France, out of twenty-four cases applying the CISG, it appears that parties seriously addressed the issue of the applicable law in only one case. ${ }^{24}$ Turning to arbitration, a study of thirty arbitral awards that applied the CISG reveals that the parties provided for the applicable law in only 60 per cent of the cases. ${ }^{25}$

Of course, these are small sample sizes, and it may be that so few contracts are ever litigated that this is an unrepresentative group. However, in some ways that is the point. If litigation is rare and parties draft their contracts without much concern for the applicable law, then we should at least question how important having a fully harmonized regime actually is. Instead, it seems likely that the prior course of dealing among contracting parties, their cultural expectations, their sense of shared norms, and so forth are at least as important as the universalist rules provided by the Convention.

\section{The CISG's influence on the pluralist development of transnational contract law}

None of the preceding discussion should be taken to mean that having a convention on the international sale of goods is a bad idea or somehow has no effect at all. But the important impacts of the CISG may arise in different and more subtle ways than its proponents generally assume. This last section suggests two ways that the CISG likely shapes the pluralist development of transnational contract law.

\section{The CISG as a potential force for shifting legal consciousness}

Law helps to shape norms and expectations over time, and those norms slowly become part of legal consciousness - the day-to-day sense people have regarding 'the way things are'. Thus, the rules embodied in the CISG are both derived from commercial practice and, over time, will inevitably shape commercial culture in

21 See Gilles Cuniberti, 'Is the CISG Benefitting Anybody?' (2006) 39 Vanderbilt Journal of International Law 1511, 1529-38.

22 Ibid 1529-30.

23 Ibid 1532-3.

24 Ibid 1534-5.

25 Ibid 1535-6. 
an endless feedback loop. Accordingly, it may be that the existence of the CISG will contribute to a harmonization of social practice as people imbibe the expectations codified in the Convention. And courts may, over time, also interpret their own local contractual regimes with reference to the Convention and its norms, which also contributes to harmonization over time.

This subtle process of norm development may ultimately be the way in which the CISG most contributes to harmonization-not by literally enforcing uniformity but, rather, by influencing the pluralist development of transnational contract law. Socio-legal scholars have long argued that law operates as much by influencing modes of thought as by determining conduct in any specific case. ${ }^{26}$ It is a constitutive part of culture, shaping and determining social relations ${ }^{27}$ and providing 'a distinctive manner of imagining the real'. ${ }^{28}$

For example, '[l] ong before we ever think about going to a courtroom, we encounter landlords and tenants, husbands and wives, barkeeps and hotel guests - roles that already embed a variety of juridical notions' ${ }^{29}$ Indeed, we cannot escape the categories and discourses that law supplies. ${ }^{30}$ These categories may include ideas of what is public and what is private, who is an employer and who is an employee, what precautions are 'reasonable', who has 'rights', and so on. ${ }^{31}$ In short, 'it is just about impossible to describe any set of "basic" social

26 See, eg, Kristin Bumiller, The Civil Rights Society (Johns Hopkins University Press 1988) 30-2 (examining 'the role of legal ideology in structuring mass consciousness'); P Ewick and SS Silbey, The Common Place of Law: Stories from Everyday Life (Newberry Library 1998) 45 (defining 'legal consciousness' and arguing that 'every time a person interprets some event in terms of legal concepts or terminology - whether to applaud or to criticize, whether to appropriate or to resist-legality is produced' and 'repeated invocation of the law sustains its capacity to comprise social relations'); Michael W McCann, Rights at Work: Pay Equity Reform and the Politics of Legal Mobilization (University of Chicago Press 1994) 7: 'Legal (or rights) consciousness... refers to the ongoing, dynamic process of constructing one's understanding of, and relationship to, the social world through use of legal conventions and discourses'); Sally Engle Merry, Getting Justice and Getting Even: Legal Consciousness among Working-Class Americans (University of Chicago Press 1990) 5 (arguing that '[1] egal consciousness is expressed by the act of going to court as well as by talk about rights and entitlements' and that such '[c]onsciousness develops through individual experiences'); Susan S Silbey, 'Making a Place for Cultural Analyses of Law' (1992) 17 Law and Social Inquiry 39, 42 (noting that 'law contributes to the articulation of meanings and values of daily life').

27 See, eg, Silbey (n 26) 41 (arguing that 'law is a part of the cultural processes that actively contribute in the composition of social relations').

28 Clifford Geertz, Local Knowledge: Further Essays in Anthropology (Basic Books 1983) 173.

29 A Sarat and J Simon, 'Beyond Legal Realism? Cultural Analysis, Cultural Studies, and the Situation of Legal Scholarship' (2001) 13 Yale Journal of Law and Humanity 3, 20.

30 Robert W Gordon, 'Critical Legal Histories' (1984) 36 Stanford Law Review 57, 105: '[I]n actual historical societies, the law governing social relations-even when never invoked, alluded to, or even consciously much thought about-has been such a key element in the constitution of productive relations that it is difficult to see the value... of trying to describe those relations apart from law.'

31 Indeed, according to Sarat and Kearns: 'Perhaps the most stunning example of law's constitutive powers is the willingness of persons to conceive of themselves as legal subjects, as the kind of beings the law implies they are-and needs them to be. Legal subjects think of themselves as competent, self-directing persons who, for example, enter bargained-for exchanges as free and equal agents.' A Sarat and TR Kearns, 'Beyond the Great Divide: Forms of Legal Scholarship and Everyday Life' in Austin Sarat and Thomas R Kearns (eds), Law in Everyday Life (University of Michigan Press 1993) $21,28$. 
practices without describing the legal relations among the people involved-legal relations that don't simply condition how the people relate to each other but to an important extent define the constitutive terms of the relationship'. ${ }^{32}$

Because legal categories and ideas suffuse social life, ${ }^{33}$ scholars have studied both how people think about the law and the ways in which largely inchoate ideas about the law can affect decisions they make. ${ }^{34}$ Sally Engle Merry observes legal consciousness in "the way people conceive of the "natural" and normal way of doing things, their habitual patterns of talk and action, and their commonsense understanding of the world'. ${ }^{35}$ These understandings are often taken for granted. This is because legal consciousness may be so much a part of an individual's worldview that it is present even when law is seemingly absent from an understanding or construction of life events. ${ }^{36}$ Thus, '[w]e are not merely the inert recipients of law's external pressures. Rather, we have imbibed law's images and meanings so that they seem our own'. ${ }^{37}$ Law is an often unnoticed, but nevertheless crucial, presence in our ideas of what is fair, appropriate, or natural. ${ }^{38}$

32 Gordon (n 30) 103.

33 See MC Suchman and LB Edelman, 'Legal Rational Myths: The New Institutionalism and the Law and Society Tradition' (1996) 21 Law and Social Inquiry 903, 907: 'Law and Society scholarship depicts the law as a culturally and structurally embedded social institution.'

34 Indeed, various authors have explored the legal consciousness of average citizens. See, eg, Bumiller (n 26); Ewick and Silbey (n 26); Malcom M. Feeley, The Process Is the Punishment: Handling Cases in a Lower Criminal Court (Russell Sage Foundation 1979); McCann (n 26), Merry (n 26); Barbara Yngvesson, Virtuous Citizens, Disruptive Subjects: Order and Complaint in a New England Court (Routledge 1993); P Ewick and SS Silbey, 'Conformity, Contestation, and Resistance: An Account of Legal Consciousness' (1992) 26 New England Law Review 731; Laura Beth Nielsen, 'Situating Legal Consciousness: Experiences and Attitudes of Ordinary Citizens about Law and Street Harassment' (2000) 34 Law and Society Review 1055; Austin Sarat, “"The Law Is All Over”: Power, Resistance, and the Legal Consciousness of the Welfare Poor' (1990) 2 Yale Journal of Law and the Humanities 343; A Sarat and WLF Felstiner, 'Lawyers and Legal Consciousness: Law Talk in the Divorce Lawyer's Office' (1989) 98 Yale Law Journal 1663.

35 Merry (n 26) 5; see also Gordon (n 30) 101 (arguing that we should 'treat legal forms as ideologies and rituals whose "effects"-effects that include people's ways of sorting out social experience, giving it meaning, grading it as natural, just, and necessary or as contrived, unjust and subject to alteration-are in the realm of consciousness'); Sarat and Simon (n 29) 19: 'Law is part of the everyday world, contributing powerfully to the apparently "stable, taken-for-granted quality of that world and to the generally shared sense that as things are, so must they be"' (quoting Sarat and Kearns (n 31) 30).

36 See David M Trubeck, 'Where the Action Is: Critical Legal Studies and Empiricism' (1984) 36 Stanford Law Review 575, 604: 'Law, like other aspects of belief systems, helps to define the role of an individual in society and the relations with others that make sense'; see also Jean Comaroff, Body of Power, Spirit of Resistance: The Culture and History of a South African People (University of Chicago Press 1985) 4-5 (arguing that consciousness is 'embedded in the practical constitution of everyday life, part and parcel of the process whereby the subject is constructed by external sociocultural forms').

37 Sarat and Kearns (n 31) 29. See also Gordon (n 30) 109: '[T] he power exerted by a legal regime consists less in the force that it can bring to bear against violators of its rules than in its capacity to persuade people that the world described in its images and categories is the only attainable world in which a sane person would want to live.'

38 See Gordon (n 30) 111: 'In short, the legal forms we use set limits on what we can imagine as practical options: Our desires and plans tend to be shaped out of the limited stock of forms available to us: The forms thus condition not just our power to get what we want but what we want (or think we can get) itself.' Indeed, scholars have noted that people's judgments about praise and blame will often match the corresponding legal categories, even when those people are not familiar in detail with legal rules and doctrines. See generally Max Gluckman, The Allocation of 
This focus on law in everyday life ${ }^{39}$ recognizes that people interpret their experiences by drawing on a collaboration of law and other social structures. ${ }^{40}$ These interpretations may be widely varied and will, of course, depend partly on social class, prior contacts with the law, and political standing. ${ }^{41}$ Nevertheless, legal consciousness constitutes an ongoing interaction between official norms as embodied in the common sense categories of daily life and each individual's participation in the process of constructing legality. ${ }^{42}$ Accordingly, legal consciousness includes the ways in which individuals themselves deploy, transform, or subvert official legal understandings and thereby 'construct' law on the ground. ${ }^{43}$ We all take part in the construction of legal consciousness, even as we are also inevitably affected by the legal categories of the social structures around us.

Although a detailed discussion of the legal consciousness literature is beyond the scope of this article, it seems clear that an international law instrument such as the CISG provides a mechanism for influencing cognitive categories and behaviour over time. And while it is difficult to definitively prove a direct causal link between a legal conception and an individual's category of thought, it does not mean that such processes are not very powerful determinants of how we think. Accordingly, what it means to enter into a transnational business relationship,

Responsibility (Manchester University Press 1972) 109, 155-8 (collecting essays by multiple authors analyzing similarities between industrialized societies and primitive African tribes in terms of their legal systems and behavioral patterns).

39 See, eg, A Sarat and T R Kearns, Law in Everyday Life (Michigan University Press 1993).

40 DM Engel and FW Munger, 'Rights, Remembrance, and the Reconciliation of Difference' (1996) 30 Law and Society Review 7, 14 (asserting that their 'study points to the mutuality and inseparability of law, culture, identity and experience' and that '[1] aw is one of the elements that constitute the categories and routines of everyday life'); Sarat (n 34) 346 (arguing that welfare recipients, for example, 'use legal ideas to interpret and make sense of their relationship to the welfare bureaucracy even as they refine those ideas by making claims the meaning and moral content of which are often at variance with dominant understandings').

41 See, eg, Davina Cooper, 'Local Government Legal Consciousness in the Shadow of Juridification' (1995) 22 Journal of Law and Society 506, 510: '[L]aw is understood experientially, in ways shaped by class, education, geography, and occupational positioning.' C Seron and F Munger, 'Law and Inequality: Race, Gender . . . and, of Course, Class' (1996) 22 Annual Review of Sociology 187, 202 (asserting that ' $\mathrm{t}$ ] he relationship between lawyers and the evolution of... the class system[] should be a prime area for continuing development of theory and research').

42 'Legality' is defined as those meanings, sources of authority, and cultural practices that are in some sense legal although not necessarily approved or acknowledged by official law. The concept of legality offers the opportunity to consider 'how, where and with what effect law is produced in and through commonplace social interactions.... How do our social roles and statuses, our relationships, our obligations, prerogatives, and responsibilities, our identities, and our behaviors bear the imprint of law?' Ewick and Silbey (n 26) 20. See also Sarat and Kearns (n 31) 55: 'Law is continuously shaped and reshaped by the ways it is used, even as law's constitutive power constrains patterns of usage.'

43 See, eg, Austin Sarat, 'Redirecting Legal Scholarship in Law Schools' (2000) 12 Yale Journal of Law and Humanity 129, 140 (reviewing Paul Kahn, The Cultural Study of Law (1999)): 'Contests over meaning in courts or communities ... become occasions for [sociolegal scholars to observe] the play of power. Meanings that seem natural, or taken-for-granted, are described as hegemonic, but because the construction of meaning through law is, in fact, typically contested, scholars show the many ways in which resistance occurs') (citation omitted). For discussions of these forms of resistance, see Ewick and Silbey (n 26); Merry (n 26); Yngvesson (n 34). 
how contracts work, what expectations are 'reasonable,' and so on will all be shaped at least partially by the framework the Convention promulgates and inculcates. Thus, the Convention may have long-term impacts on the harmonization of cultural expectations and cognitive categories. However, this is a very different type of process from the top-down unification regimes usually envisioned when conventions of this sort are drafted.

\section{The CISG as a potential forum for dialogue among multiple jurisdictions}

Harmonization proponents tend to view legal pluralism, jurisdictional overlap, and hybrid legal spaces as a problem to be solved by stamping it out, rather than as a reality to be shaped and influenced over time. Indeed, even when jurisdictional overlap or regulatory interdependence is undeniable, we see what Robert Ahdieh has termed 'the standard dualist response'. ${ }^{44}$ Law seeks to delimit each entity's jurisdiction and authority more effectively and thereby eliminate such overlap. This paradigm of jurisdictional line drawing has been prevalent both in the international/transnational realm ${ }^{45}$ and in discussions of federalism, ${ }^{46}$ as courts and scholars try to demarcate distinct spheres for state and federal authority. As Ahdieh notes, '[s] uch reactions are hardly surprising. At heart, they reflect some visceral sense of law's project as one of categorization, clear definition, and line-drawing. 47

Yet this single-minded focus on certainty and clarity not only fails to describe a globalized world of inevitable cross-border jurisdictional overlap but also ignores the crucial question of whether leaving open space for such overlapping regulatory authority might actually be beneficial. Indeed, while jurisdictional overlap is frequently viewed as a problem because it potentially creates conflicting obligations and uncertainty, we might also view jurisdictional redundancy as a necessary adaptive feature of a multivariate, pluralist legal system. The very existence of

44 Robert B Ahdieh, 'Dialectical Regulation' (2006) 38 Connecticut Law Review 863, 867.

45 For example, debates in the USA about judicial citation of foreign authority have often centred around delineating when it is permissible and when impermissible to reference foreign or international law. See, eg, Melissa A Waters, 'Creeping Monism: The Judicial Trend toward Interpretive Incorporation of Human Rights Treaties' (2007) 107 Columbia Law Review 628. Similarly, theories of jurisdiction and choice of law have long sought to provide a single answer to the question of which law should apply to a cross-border dispute. Compare Pennoyer v Neff [1877] 95 US 714 (holding that states have complete authority within their territorial boundaries but no authority outside those boundaries), with Int'l Shoe Co v Washington [1945], 326 US 310, 316 (establishing a test for determining whether an assertion of personal jurisdiction comports with the due process clause of the US Constitution on the basis of whether the defendant had sufficient contacts with the relevant state 'such that the maintenance of the suit does not offend "traditional notions of fair play and substantial justice"' (quoting Milliken v Meyer [1940] 311 US 457, 463); compare also Restatement (First) of Conflict of Laws $\$ 378(1934)$ : 'The law of the place of wrong determines whether a person has sustained a legal injury' with Restatement (Second) of Conflict of Laws $\$ 6 \mathrm{cmt}$. c (1971) (providing a more flexible inquiry aimed at determining the place with the 'most significant relationship' to the dispute in question).

46 See Robert A Schapiro, 'Toward a Theory of Interactive Federalism' (2005) 91 Iowa Law Review 243.

47 Ahdieh (n 44) 867. 
overlapping jurisdictional claims often leads to a nuanced negotiation-either explicit or implicit-between or among the various communities making those claims. ${ }^{48}$ And what is likely to emerge is an amalgam of local and international law that may aid the development of each.

In focusing on the pluralist opportunities inherent in jurisdictional overlap, I echo the insights of Robert Cover's article 'The Uses of Jurisdictional Redundancy'. ${ }^{49}$ Cover analysed American federalism and celebrated the benefits that accrue from having multiple overlapping jurisdictional assertions. Such benefits include a greater possibility for error correction, a more robust field for norm articulation, and a larger space for creative innovation. ${ }^{50}$ Moreover, when decision makers are forced to consider the existence of other possible decision makers, they may tend to adopt, over time, a more restrained view of their own power and come to see themselves as part of a larger tapestry of decision making in which they are not the only potentially relevant voice. Finally, although Cover acknowledged that it might seem perverse 'to seek out a messy and indeterminate end to conflicts which may be tied neatly together by a single authoritative verdict', he nevertheless argued that we should 'embrace' a system 'that permits tensions and conflicts of the social order' to be played out in the jurisdictional structure of the system. ${ }^{51}$ More recently, Judith Resnik has noted the 'multiple ports of entry' that a federalist system creates ${ }^{52}$ and has argued that what constitutes the appropriate spheres for 'local', 'national', and 'international' regulation and adjudication changes over time and should not be essentialized. ${ }^{53}$

Building on these principles, we can perhaps identify two different strategies for responding to legal pluralism. On the one hand, when facing an issue of intersystemic complexity, we can seek to bring order by engaging in pre-emption, line drawing, and delimiting separate spheres of authority. This is what Cover calls a 'jurispathic' approach because it necessarily requires the decision maker to anoint one legal regime as the legitimate authority and decree that all other regimes are disabled from applying their norms. In doing so, the decision maker 'kills off' conflicting interpretations and authorities. ${ }^{54}$ The contrasting approach is what

48 See Paul Schiff Berman, Global Legal Pluralism: A Jurisprudence of Law beyond Borders (Cambridge University Press 2012) 236-43.

49 Robert M Cover, 'The Uses of Jurisdictional Redundancy: Interest, Ideology, and Innovation' (1981) 22 William and Mary University Law Review 639.

50 Ibid.

51 Ibid 682.

52 See Judith Resnik, 'Law's Migration: American Exceptionalism, Silent Dialogues, and Federalism's Multiple Ports of Entry' (2006) 115 Yale Law Journal 1564.

53 See Judith Resnik, ‘Afterword: Federalism's Options' (1996) 14 Yale Law and Policy Review 465, 473-4: 'My point is not only that particular subject matter may go back and forth between state and federal governance but also that the tradition of allocation itself is one constantly being reworked; periodically, events prompt the revisiting of state or federal authority, and the lines move.'

54 See Robert M Cover, 'The Supreme Court, 1982 Term-Foreword: Nomos and Narrative' (1983) 97 Harvard Law Review 4, 53. 
Cover would call 'jurisgenerative, ${ }^{55}$ This pluralist approach seeks modes of accommodation, deference, and hybridity that will allow multiple jurisdictions to continue to speak to a particular legal problem, without blocking the dialogue among systems. ${ }^{56}$ In the context of the CISG, we might look at all of the various forms of pluralism that were identified previously not as problems but, rather, as opportunities to foster a dialogue among transnational business norms, statebased norms, and the norms articulated in the Convention.

To see how this dialogic approach might work, it may be instructive to look at the way that one common law judge, US Supreme Court Justice Ruth Bader Ginsburg, navigates the relative domains of state and federal sovereignty. Often, as with international versus national law, such choices are built on binary decision making and clear lines of demarcation. Either a case is within state jurisdiction or federal; either state law or federal law applies, and so on. But Ginsburg tends to favour overlapping jurisdictional schemes and more deferential accommodation of multiple interests. In the three cases that follow, she works hard to achieve this sort of pluralist resolution, even when the path for doing so is less than obvious.

The first is Gasperini v Center for Humanities, Inc. ${ }^{57}$ In this case, the Court continued a line of cases considering when a federal court hearing a state claim should apply state or federal law. Ever since the US Supreme Court's landmark decision in Erie Railroad $v$ Tompkins, federal courts hearing state claims are required to apply state substantive law, essentially as if the case were being decided in a state court. ${ }^{58}$ But, what happens if applying the state law conflicts with the rules governing the general operation of federal courts? These are some of the knotty problems in what has become known as the Erie doctrine.

Gasperini presented a particularly difficult application of the doctrine because both the state and federal interests at stake were so strong. New York had passed a tort-reform statute that sought to rein in what were perceived to be excessive jury awards. ${ }^{59}$ Under the statute, state appellate courts were empowered to review the size of jury verdicts and to order new trials whenever the jury's award 'deviates materially from what would be reasonable compensation'.$^{60}$ Thus, it would seem that, if such a situation happened to arise in a state law case brought in federal court, the federal appellate court should, pursuant to Erie and its progeny, apply the New York law allowing appellate re-examination of the jury verdict. However, under the Seventh Amendment of the US Constitution, which governs

55 Ibid 11-15.

56 See Judith Resnik, 'Living Their Legal Commitments: Paideic Communities, Courts, and Robert Cover (An Essay on Racial Segregation at Bob Jones University, Patrilineal Membership Rules, Veiling, and Jurisgenerative Practices)' (2005) 17 Yale Journal of Law and Humanity 17, 25: '[Cover] wanted the state's actors...to be uncomfortable in their knowledge of their own power, respectful of the legitimacy of competing legal systems, and aware of the possibility that multiple meanings and divergent practices ought sometimes to be tolerated, even if painfully so.'

57 Gasperini v Center for Humanities, Inc [1996] 518 US 415.

58 Erie Railroad Co v Tompkins [1938] 304 US 64.

59 Gasperini v Center for Humanities, Inc [1996] 518 US 423.

60 NY CPLR \$5501(c) (McKinney 1995). 
proceedings in federal court but not in state court, 'the right of trial by jury shall be preserved, and no fact tried by a jury, shall be otherwise re-examined in any Court of the United States, than according to the rules of the common law' ${ }^{61}$ This provision would normally block a federal court from conducting the sort of review mandated by the New York law. Accordingly, the Supreme Court was faced with the question of which rule would prevail in a state-law suit brought in a federal court in New York.

Justice Scalia, in dissent, took the jurispathic path, arguing categorically that federal courts must follow the Seventh Amendment's command regardless of what a New York court would do. ${ }^{62}$ Thus, the New York law would have no impact at all in a federal suit of this kind. In contrast, Justice Ginsburg worked hard to create a Solomonic solution, whereby both New York's tort-reform interests and the Seventh Amendment could be accommodated. To do this, Ginsburg construed the Seventh Amendment's re-examination clause to apply to federal appellate courts but not to the traditional power of federal trial judges to grant new trials notwithstanding a contrary jury verdict. ${ }^{63}$ Thus, she reasoned that New York's law controlling compensation awards for excessiveness or inadequacy could be given effect, without detriment to the Seventh Amendment, if the review standard set out in the state statute were applied by the federal trial court judge, with appellate control of the trial court's ruling confined to 'abuse of discretion'. ${ }^{64}$ Under this approach, the trial judge could apply state law reviewing the jury verdict, thereby retaining this state policy choice in state law cases tried in federal courts, ${ }^{65}$ while the Seventh Amendment prohibition on reexamining jury verdicts would continue to bind the federal appellate court (absent a flagrant abuse of discretion). ${ }^{66}$

Whatever one thinks of the soundness of Ginsburg's historical and jurisprudential analysis, what is most significant is the extraordinarily creative way in which Ginsburg worked to accommodate both state and federal interests. Had the Court adopted Justice Scalia's approach, a litigant from outside New York involved in a state law suit with a New Yorker would be able to avoid the state's tort-reform provision simply by filing that case in, or removing that case to, federal court. On the other hand, had the Court simply applied the state law without limitations, it would have been ignoring the significant command of the US Constitution regarding the sanctity of jury verdicts. By splitting the difference, the Court arguably protected the core of both state and federal interests at stake.

In Shady Grove Orthopedic Associates, P.A. v Allstate Insurance Co., ${ }^{67}$ Ginsburg again sought to vindicate both state and federal interests in an Erie case. This time

61 US Constitution, Amendment VII.

62 Gasperini (n 57) 450 (Scalia, J, dissenting).

63 Ibid 432-5.

64 Ibid 419.

65 Ibid 437-9.

66 Ibid 419.

67 Shady Grove Orthopedic Associates, PA v Allstate Insurance Co [2010] 559 US 393. 
the question was whether, in a federal court, Rule 23 of the Federal Rules of Civil Procedure, governing class actions, would override another New York state law, this one aimed at preventing certain kinds of suits from being brought as class actions. Justice Scalia's plurality opinion took the jurispathic position that because the state law addressed class action suits it was necessarily trumped by Rule 23 in cases heard in federal courts. ${ }^{68}$ Ginsburg, in dissent, chose a more nuanced reading. She took Scalia to task for 'relentlessly' making choices that would override state law. ${ }^{69}$ Instead, she pointed out - in true pluralist fashion-that 'before undermining state legislation' the Court should ask whether the federal and state laws truly conflict. ${ }^{70}$ Thus, in contrast to the plurality opinion, she 'would continue to interpret Federal Rules with awareness of, and sensitivity to, important state regulatory policies'. ${ }^{71}$ Taking this approach, she read Rule 23 to dictate only the procedures for certifying and pursuing a class action claim. In contrast, she argued, the New York state law addressed what sort of relief could be pursued through the class mechanism. ${ }^{72}$ And, as with Gasperini, regardless of whether one agrees with her particular way of accommodating both federal and state law, there can be no doubting her passion to pursue an approach to Erie that attempts to provide maximum space for the effectuation of important state policy judgments.

Ginsburg's approach to federal pre-emption law seems to suggest the same impulse towards mutual accommodation and splitting the difference. For example, in American Airlines, Inc. $v$ Wolens, ${ }^{73}$ the question was whether the federal law deregulating the airline industry pre-empted state consumer fraud and breach-of-contract claims brought against American Airlines related to changes the airline made unilaterally and retroactively to its frequent-flyer program. Two justices argued that federal law pre-empted both the fraud and contract claims, ${ }^{74}$ while another argued that neither type of claim should be deemed pre-empted. ${ }^{75}$ Ginsburg, writing for the Court, took the middle ground, holding that federal law pre-empted the fraud claims but not the contract claims. ${ }^{76}$ The Airline Deregulation Act explicitly pre-empted state-imposed regulation 'relating to [air carrier] rates, routes, or services, ${ }^{, 77}$ which would include consumer fraud claims based in state law. ${ }^{78}$ However, the contract claims, she concluded, were based not on state regulation but, rather, on claimed breaches of terms agreed

68 Ibid 398-406.

69 Ibid 437 (Ginsburg, J, dissenting).

70 Ibid (Ginsburg, J, dissenting).

71 Ibid (Ginsburg, J, dissenting).

72 Ibid 446-7 (Ginsburg, J, dissenting).

73 American Airlines, In. $v$ Wolens [1995] 513 US 219.

74 Ibid 238 (O'Connor, J, concurring and dissenting).

75 Ibid 235 (Stevens, J, concurring and dissenting).

76 Ibid 222.

77 Ibid 221-2 (quoting 49 USC \$ 1305(a)(1).

78 Ibid 228. 
upon by the parties themselves. Thus, they could be maintained without running afoul of the Airline Deregulation Act. ${ }^{79}$

In each of these cases, we see Ginsburg working mightily to make subtle distinctions so as to preserve space for both federal and state interests to be vindicated. Indeed, none of the conclusions Ginsburg reached were clearly dictated by the cases, rules, or statutes she interpreted. ${ }^{80}$ Thus, they are actually best understood as efforts to maintain a pluralist structure to American federalism, one that will allow sufficient play in the joints and overlapping jurisdiction so that all sovereignties are afforded an opportunity to weigh in with policy judgments. So too it can be for the CISG, with judges (and contracting parties) building an amalgam of international and local law, through both interpretation and norm inculcation over time.

\section{Conclusion}

When we move beyond the rhetoric and look at the CISG in practice, it strikes me that what we find is not the top-down unification of diverse local law that we might first have expected and that some proponents of the CISG assume is the sole aim of the entire harmonization effort. Instead, we see a document not only assembled from pluralist civil and common law influences but also one that is itself inevitably subject to pluralist influences. First, even the Convention's unifying language can be interpreted in different ways based on different linguistic and legal contexts. Second, there are many important areas of transnational contract law deliberately excluded from the CISG and thereby left subject to multiple regulatory regimes. Third, even in areas covered by the Convention, the very text of the document builds in lacunae where local legal traditions or conflictof-laws principles will fill the void. Fourth, the language of the Convention inevitably contains ambiguities that are subject to multiple interpretations. And, of course, we know that in many cases parties will often rely more on their various business contexts and cultures and less on the unifying vision of international law.

However, all this pluralism does not mean the CISG is flawed or a failure. It just means that we need to recognize the inevitable pluralism within universal harmonization schemes. And if we want to move towards a set of more broadly held norms, we need to understand that such change will come gradually, through shifts in legal consciousness over time and through nuanced interpretation that seeks to knit together local and international norms into a new combination that builds pluralism into the fabric of the regime. In the end, pluralism may provide a more durable framework for evaluating the long-term efficacy of an international legal instrument than the false hope of imposed universality.

79 Ibid 228-9.

80 See, eg, Richard D Freer, 'Some Thoughts on the State of Erie After Gasperini' (1998) 76 Texas Law Review 1637 (criticizing the decision). 